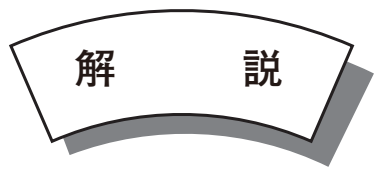

\title{
自己形成過程を原子レベルで制御した量子ドットの作製と高機能光応答の実現 \\ Atomically Controlled Growth of Self-Assembled Quantum Dots and Realization of Highly Functional Optical Responses
}

喜多隆*

Takashi KITA

Key Words: Quantum Dot, InAs/GaAs, Semiconductor Photonic Device, Optical Amplifier

\section{1. 緒 言}

理想的な量子ドットは 3 方向に閉じ込めたゼロ次元の量 子構造である。量子構造には 1 次元方向に閉じ込めた量子 井戸、2 次元方向に閉じ込めた量子細線、そして量子ドッ トがある。閉じ达め次元とは、作る立場からいえば制御 が必要な次元の数である。すなわち、量子ドットを作るに は 3 方向に結晶成長を制御せねばならない。量子井戸を作 製するには 1 次元方向の制御だけでよい。これは結晶成長 における原料の供給を制御することで、成長の時間軸方向 の制御を結晶の成長方向に投影したものである。いかに精 密に成長を制御するかがへテロ界面の急峻性、量子井戸 幅、量子構造の繰り返しの精度を決定する。原子層のレベ ルで原子を供給することができれば量子効果に基づいた 人工的な新しい結晶ができる ${ }^{1)}$ 。この革命的なアイデアは 分子線エピタキシー (Molecular Beam Epitaxy: MBE) や有機 金属気相エピタキシー (Organometallic Vapor Phase Epitaxy: OMVPE) などの結晶成長技術の発展とともに 1970 年代以 降の半導体物理とデバイス技術の発展を決定的にし、強力 に铱引した。半導体中の電子状態を量子化することで、状 態密度は劇的に変化し、狭い空間に閉じ込められた電子と 正孔、あるいはそれらのペアである励起子が創る物性は新 しいデバイスを次々に生み出した。量子構造の閉じ込め次 元を下げることによって、電子状態をより強力に制御でき る。このとき形成される先鋭化した状態密度はこれまでに 無い全く新しいタイプの物性を顕在化させ、新規な原理で 動作するデバイスを実現すると期待されている。

ボトムアップの結晶成長で 2 次元方向に制御した量子細 線や 3 次元方向に制御した量子ドットを作製するには、量 子井戸のような時間軸方向の制御以外に同時に働く別の仕 掛けが必要である。量子ドットのボトムアップ成長におけ るこの仕掛けが歪エネルギーである ${ }^{2,3)}$ 。後で詳しく述べる
ように、基板に対して格子不整合の大きな材料をエピタキ シャル成長すると、成長に伴ってエピタキシャル膜内部に 蓄積される格子不整合による歪エネルギーを解放するため に島状成長が始まる。このようにして作製される量子ドッ トをデバイスに利用するにはデバイス動作が要求する性能 に合うように物性を微調整することが不可欠である。これ は量子ドットの自然形成プロセスを実時間で成長中に観測 し、この結果を成長にフィードバックすることにより可能 になる。われわれは MBEにおいて大変強力なその場観察 ツールである反射高速電子線回折 (Reflection High Energy Electron Diffraction: RHEED) を利用して量子ドットの自己形 成過程を精密に分析し、量子ドットの積層技術を駆使して 3 次元構造化の実現をめざしている。われわれは近赤外領 域の光デバイスの有力な候補である InAs の量子ドットに注 目している。InAs 量子ドットは 1.3、1.55 $\mu \mathrm{m}$ 光通信波長帯 のデバイスを GaAs や InP 基板上に成長できるため非常に 注目されている4)。本論文では、RHEED による InAs/GaAs 量子ドット成長過程の精密な解析について紹介し、量子 ドットの積層成長技術と基礎物性 ${ }^{5-8)}$ 、積層量子ドットの偏 波制御特性 ${ }^{9-13)}$ 、および最近のデバイスへの応用 ${ }^{14-16)} に つ$ いて述べる。

\section{2. 量子ドットの自己形成}

格子定数の不整合が大きな系でへテロエピタキシャル成 長を行うと、成長に伴って歪エネルギーが蓄積して系全体 の自由エネルギーを押し上げる。格子不整合の程度によっ てヘテロエピタキシャル成長による自由エネルギーの変化 が異なる ${ }^{17)}$ 。非常に大きな格子不整合がある場合、成長に 伴い基板面上に 2 次元成長し、その後直ちに転位が入り自 由エネルギーはそれ以上増加しなくなる。いわゆるメ夕モ ルフィック成長である。一方、その逆の極端な場合、すな わち格子不整合が小さな場合は十分大きな膜厚の 2 次元的

\footnotetext{
* 神戸大学大学院工学研究科 電気電子工学専攻（657-8501 神戸市灘区六甲台町 1-1）

Department of Electrical and Electronic Engineering, Graduate School of Engineering, Kobe University

(1-1 Rokkodai, Nada, Kobe, Hyogo, 657-8501 Japan)
} 
な結晶成長が可能になる。 $\mathrm{GaAs}$ 基板に対する $\mathrm{AlGaAs}$ 系材 料の成長などがこれに相当する。ちょうどこの中間の状態 が非常に面白い。中間的な歪状態を選択することによって、 ある程度の膜厚までは 2 次元的な結晶成長を続ける。ある 膜厚に達すると歪エネルギーがエピタキシャル膜中に十分 にたまり、表面積が増える 3 次元島状に成長モードに転じ ることで表面エネルギーとして過剰な歪エネルギーの上昇 を抑えるようになる。この状態でも転位は入ることなく基 板格子と整合しながら結晶性が進む。さらに成長膜厚が増 すともはや表面エネルギーでは歪エネルギーを吸収しきれ なくなり、転位が入る。いったんこのように転移が入ると もはや島状に成長し続けることによる表面エネルギーの上 昇は損であるので、再び 2 次元的な結晶成長モードに転ず る。量子ドット形成のシナリオはざっと以上のようである。 非常に定性的な説明ではあるが、量子ドットのエピタキ シャル成長の特徵を示している。転位は無輻射再結合中心 となるので発光ダイオード、レーザ、光アンプなどでは当 然極力少ないほうが良いが、超高速な光スイッチなどでは 逆に量子ドットの非線形性を利用しながら長寿命キャリア によって生じる高速変調時のパターン効果を抑制できる点 で無輻射中心の制御が期待されている。

\section{3. 量子ドット自己形成過程のその場観察}

RHEED 観察は結晶成長その場で表面の微視的な変化を 敏感に観測できる点で非常に有効な分析手段である。われ われの MBEでは成長面はフェイスダウンの配置で設置し ており、成長表面で回折された電子線回折パターンを蛍光 板で可視化している。Fig. 1 に代表的な量子ドット成長中 の RHEED パターンを示している。量子ドットが成長する と写真のように量子ドットの島状結晶を貫通した電子線の 回折点の周辺にシェブロンパターンが現れる。このシェブ ロンパターンは基板側（Fig. 1では上側）で非常に明瞭で、 成長方向側（Fig. 1 では下側）にも弱く現れている。これ はそれぞれ電子線の屈折と反射を反映している。

われわれは屈折に起因する明瞭なシェブロンパターンに 注目し、そのシェブロンテールの開き角度（図中の $\theta$ ）が InAs の供給量とともにどのように変化するかを精密に調べ た。(Fig. 2) InAs 成長後しばらくすると約 $1.5 \mathrm{ML}$ 程度の 供給で 2 次元成長から 3 次元成長に転移する。さらに成長 を続けると、シェブロンテールの開き角 $\theta$ が徐々に大き くなる。その後、約 $2.1 \mathrm{ML}$ 以降はテール角度が一定とな り、約 $2.5 \mathrm{ML}$ を過ぎたあたりでは再びシェブロンは閉じ始 め、それとともに表面が平たんになっていることを示すス トリークロッドが中心に現れ始める。量子ドット形成初期 のシェブロンテールの開き角の増加は、成長初期の成長速 度の速い高指数面が成長速度の遅い低指数面に置き換わっ てく様子を示している。シェブロンテールの開き角が一定 になる領域では低指数面で囲まれた量子ドットに高指数面

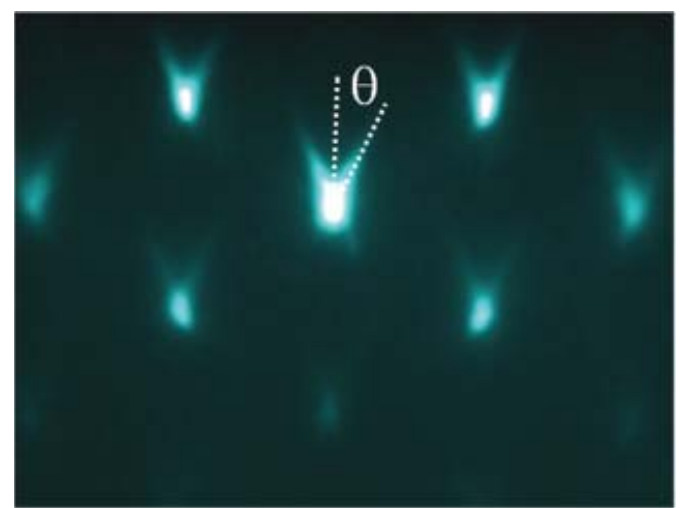

Fig.1 RHEED pattern of self-assembled InAs/GaAs QDs.

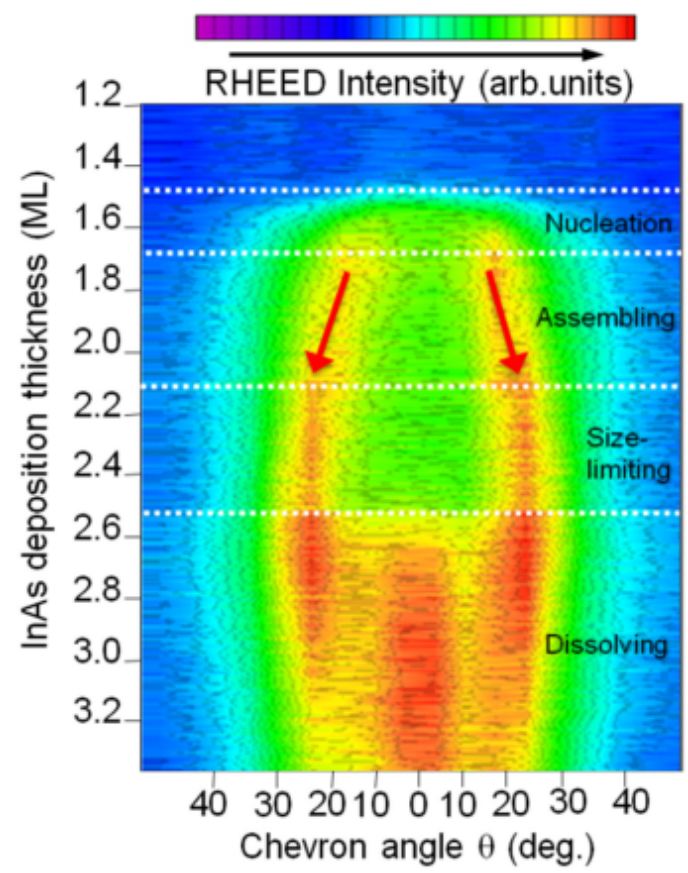

Fig. 2 RHEED-chevron angle evolution as a function of InAs-deposition thickness

で囲まれた少し遅れて成長しはじめた量子ドットの成長が 追い付き、ドットのサイズが揃いだす。さらに成長を続け ると、量子ドットに転位が入り始め、表面は再び平坦化す る。Fig. 3 にその様子を図示している。以上のように量子 ドットの成長領域は、(1) 島状成長の核ができる nucleation step、(2) In 原子が積極的に成長核に集合するとともに合 体してゆく assembling step、(3) ドットサイズが均一化する size-limiting step、(4)そして最後に過剰な歪エネルギーが転 移の導入で解放され、ドットが消失し、再び 2 次元成長に 戻る dissolving step の 4 つの領域に分類できる ${ }^{18)}$ 。

量子ドットが自己形成する過程でファセット形成がサイ 


\section{Nucleation step}

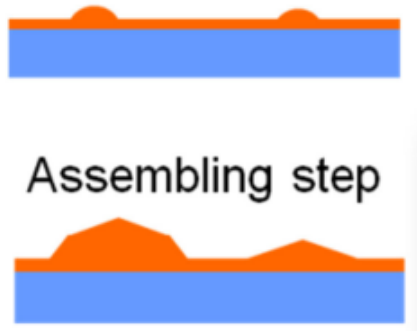

Size-limiting step

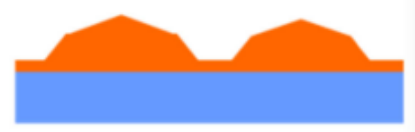

Dissolving step

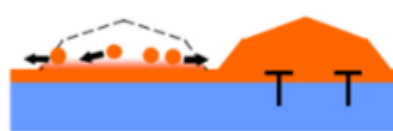

Fig. 3 Four steps in self-assembled growth of InAs/GaAs.

ズ均一化に重要な役割を果たしていることが分かった。こ のファセット構造は形状の異方性の源であり、光学応答に 敏感に影響する。われわれは電子線卜モグラフィー法を 駆使して、GaAs キャップで埋め込んだままの状態で量子 ドットの 3 次元構造を世界で初めて観察することに成功し た ${ }^{19,20)}$ 。Fig. 4 上は埋め込んだ量子ドットの 3 次元卜モグ ラフィーイメージである。白く見える部分が In 濃度の高い 部分で、極薄の InAs ぬれ層上に InAs 量子ドットが形成さ れている。(図中の黄色線は観測した立方体エリアを示す。) 量子ドットのイメージがぼやけているのは分解能が悪いか らではなく、Inが拡散しているためにぼやけて見えてい るのである。Fig. 4 下に断面イメージを未キャップの InAs 量子ドットで報告されているファセット構造と比較してみ た。頂上付近の高指数面と周辺部の低指数面は観測したイ メージを良く再現している。また、量子ドットの頂上付近 はキャップ成長中の原子の拡散によって In 濃度が低下して いることもわかる。

\section{4. 量子ドットの積層成長と光学特性の制御}

$\mathrm{InAs} / \mathrm{GaAs}$ 系量子ドットの光通信デバイスへの応用が非 常に期待されていることについてはすでに述べたが、特に
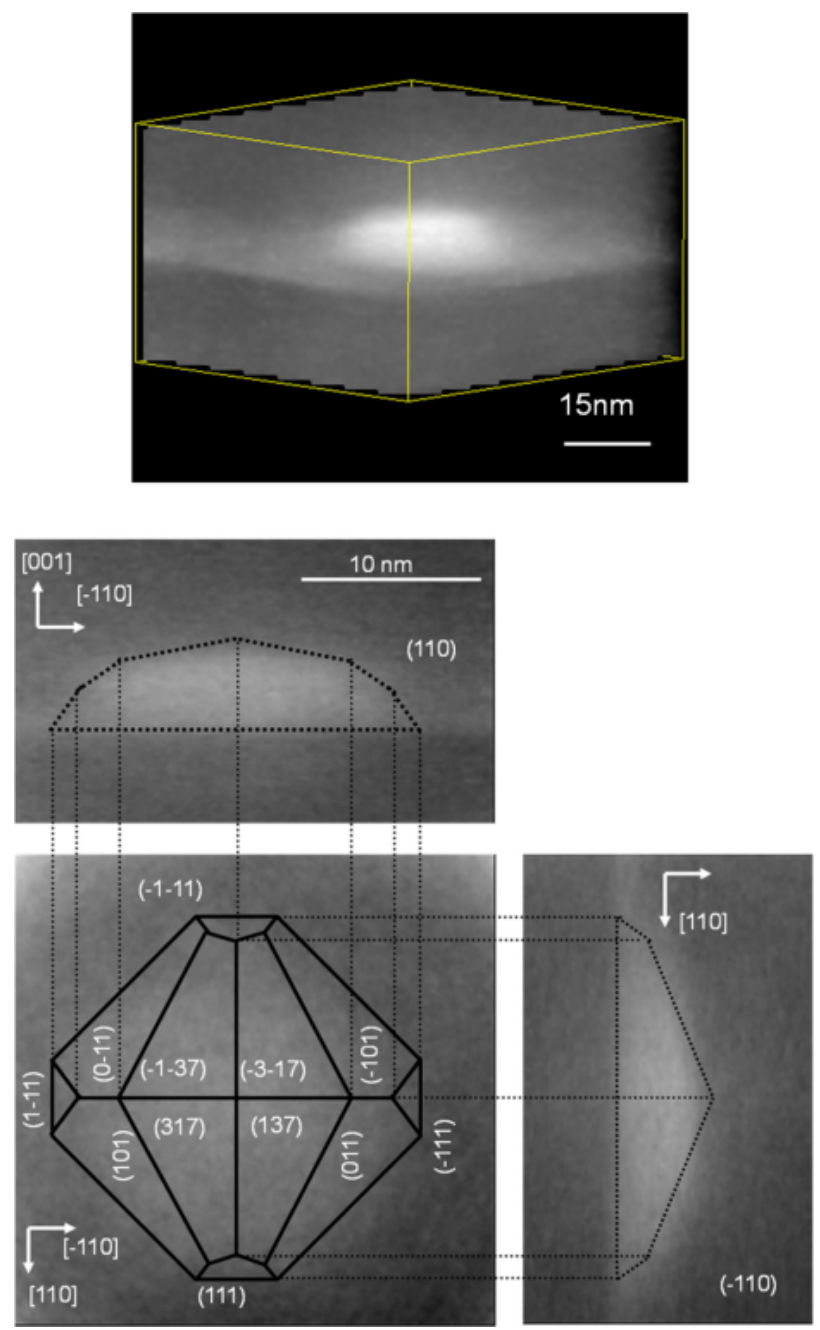

Fig. 4 Electrontomography image and a facet structure proposed for an InAs/GaAs QD.

光中継デバイスでは信号を受け取り、増幅、タイミング調 整、パルス整形をするだけでなく、必要に応じて高速なス イッチや波長変換などを施して出力することが求められ る 2,3,21,22)。このためにはデバイス特性の入力偏波に対する 依存性をなくさなければならない。通常の導波型デバイス では量子ドットは扁平であるため量子井戸と同じように TE モードにのみ強く応答する。しかしこれでは光ファイバー を伝搬して偏光がランダムになっている信号に対して等し く応答できない。この課題を解決するには量子ドットの高 さを変える必要がある。量子ドットの高さは積層成長に よって調整することができる。このような偏波無依存化の アプローチは量子井戸では不可能であり、量子ドットを利 用することで初めて解決できるユニークな点である。さら に、量子ドットサイズの不均一分布によってクロストーク の無い広帯域な光応答を実現できる。

量子ドットを積層して成長する時、量子ドット層間のス 


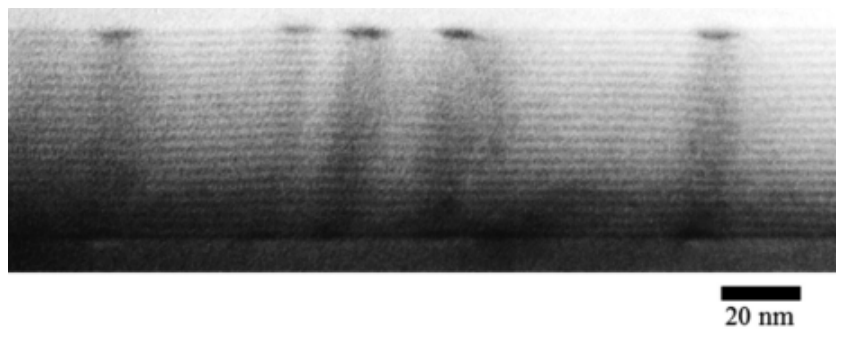

Fig. 5 TEM image of closely stacked InAs/GaAs QDs.

ペーサー層が十分薄いとき量子ドットは下層のドットの直 上に形成される。この理由は次のように説明できる。InAs 量子ドットを薄い GaAs スペーサー層でキャップすると、 下層のドットの頂上付近の $\mathrm{GaAs}$ 格子定数は広がっている ので、歪エネルギーを小さくするように下層のドットの頂 上付近に InAs が凝集しやすくなるのである。この積層成長 を繰り返すと、量子ドットが成長方向にきれいに配列して 積層し、積層数によって有効なドットの高さが自在に制御 できる。20 層積層した量子ドットの透過電子顕微鏡 (TEM) 写真を Fig. 5 に示した。この積層量子ドットの GaAs 中間 層厚は $4 \mathrm{~nm}$ である。積層した量子ドット層の wetting layer のコントラストが明瞭に見えており、積層によって柱状の 背の高い量子ドットが作製できていることがわかる。量子 ドットの高さは積層数で自在に変化させることができ、積 層量子ドットの偏波特性は、積層数に依存して劇的に変化 する。Fig. 6 にウエファ試料の端面と表面からの発光の偏 波特性を示した。室温においてフォトルミネッセンス (PL) を観測した。積層数の増加に伴って発光ピークエネルギー はわずかにシフトする。この挙動は、InGa 合金化によるブ ルーシフトと量子ドット体積の増加によるレッドシフトが 重畳しているとして理解できる。すなわち、積層初期のブ ルーシフトは合金の影響を反映しており、さらに積層を続 けると量子ドット体積増加に伴うレッドシフトが支配的に なる。また、積層に伴って [001] 偏光成分（TM 偏光成分） が増加することが分かる。これは積層方向に電子状態が結 合している直接的な証拠である。一方 Fig. 6(b) に示すよう に、(001) 面内の直線偏光異方性が積層数の増加に伴って顕 著になってくる。特に、単層の量子ドットが面内の異方性 を全く示さないのに対して、多層積層化による異方性の出 現は劇的である。

このような量子ドットの積層化による $\mathrm{TM}$ 偏波成分の出 現のメカニズムを物理的に明らかにするために、われわれ は単純化した直方体の量子ドットモデルを用いて理論計算 を実施した。4 バンドの Luttinger-Kohnハミルトニアンに 基づいた多バンド有効質量近似を利用した。Fig. 7 はその 代表的な結果である。量子ドットが積層方向に電子的に結 合することによって、偏光特性が顕著に変化することがわ

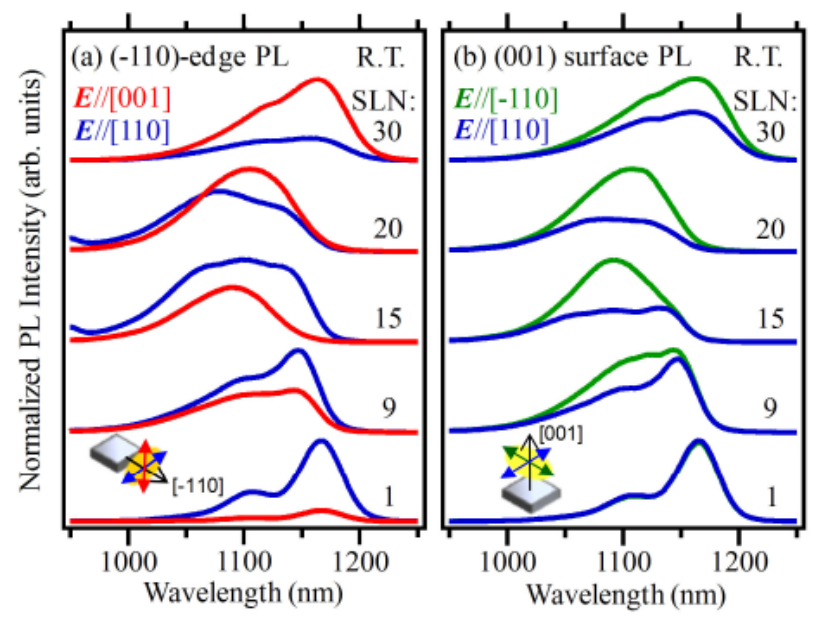

Fig. 6 PL-polarization anisotropies observed from (a) (-110)-cleaved edge and (b) (001) surface.

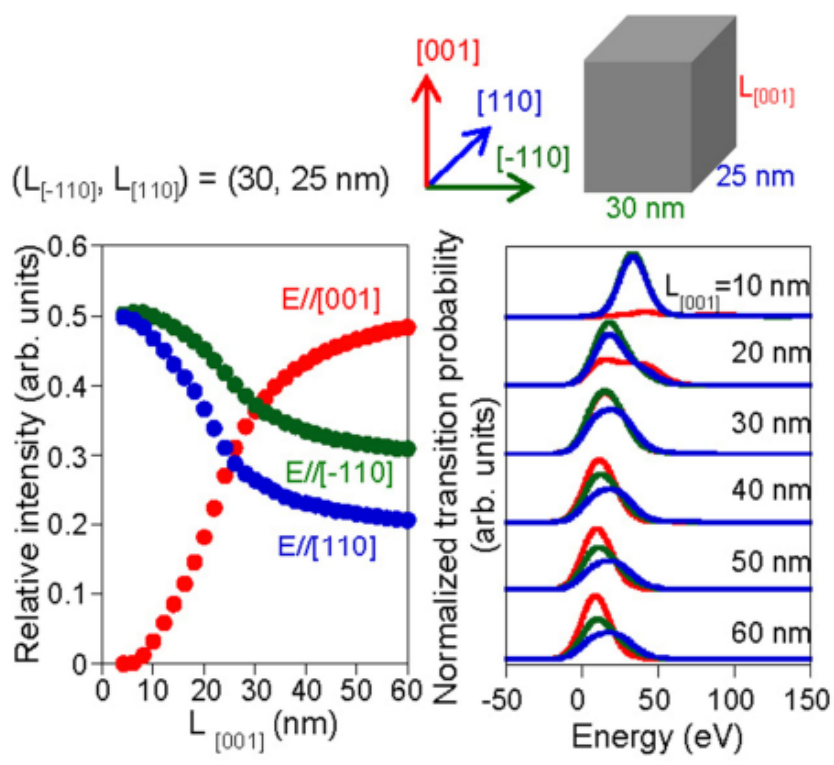

Fig. 7 Calculated transition probabilities of three polarization components as a function of QD height.

かる。[001]偏光遷移強度は顕著に強くなり、(001) 面内の 偏光異方性が顕在化する。この面内の偏光異方性の起源は Fig. 4 で明らかにした量子ドットの形状異方性とピエゾ効 果である。本理論計算より、偏波が変化するその中心的な 機構は価電子バンドにおける重い正孔と軽い正孔がミキシ ングすることによる遷移選択則の変化であることが明らか になった ${ }^{10,11)}$ 。

近接積層した量子ドットでは、上下の量子ドットの電子 状態が結合することが分かった。電子状態が結合した背の 高い量子ドットでは波動関数は非局在化する。波動関数の 
(a)

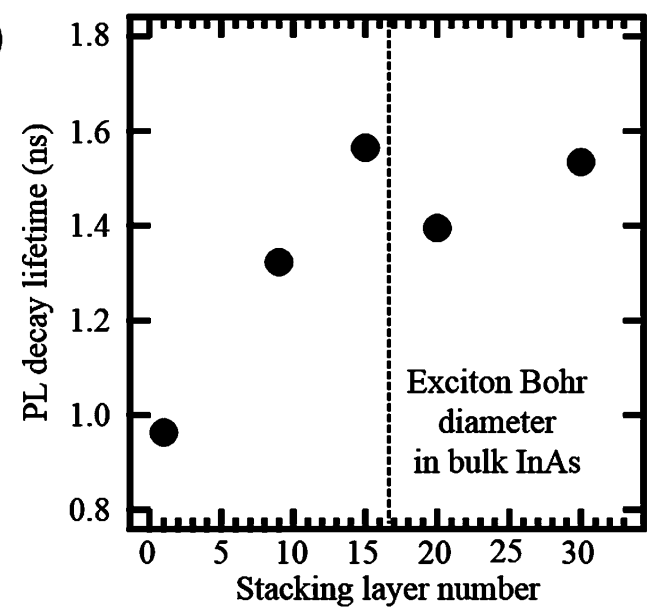

(b)

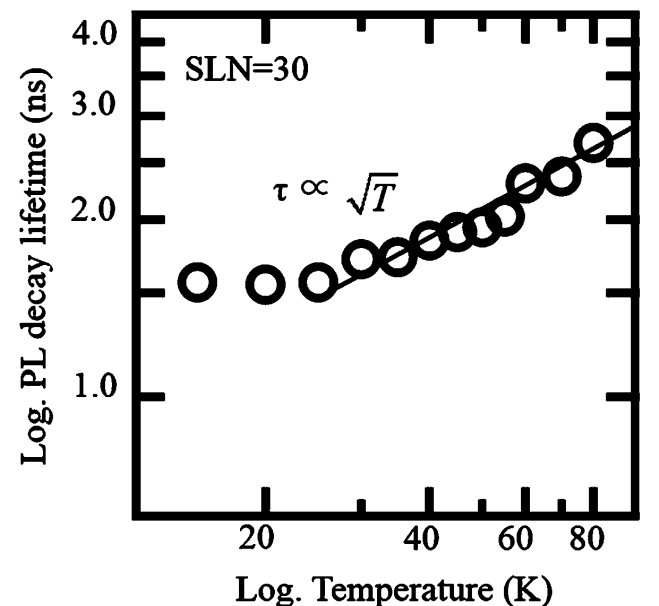

Fig. 8 SLN dependence of the PL decay lifetime profile at 3.1 K. The dashed line shows the exciton Borh diameter in bulk InAs. Temperature dependence of PL-decay lifetime of 30-stacked InAs/ GaAs QDs. The solid line indicates the T1/2 dependence.

非局在化は電子と正孔の再結合確立を下げるために発光寿 命が長くなると予想される。Fig. 8(a)に3.1 Kで測定した 発光寿命の積層数依存性を示す。発光寿命は積層に伴って 徐々に長くなり、やがて 15 層を超えたあたりで飽和する傾 向を示した。積層数による発光寿命の変化は積層量子ドッ 卜の高さに律速されており、励起子ボーア直径を超える高 さになると励起子は量子ドットの積層方向に並進運動する ことが可能になる。ここで注意すべきは積層量子ドットで は価電子带がミキシングして正孔の有効質量が小さくなっ ているため、正孔も電子と同様に非局在化して励起子の併 進運動していると考えることができる。この積層量子ドッ ト中の励起子の並進運動は積層方向の 1 次元方向にのみ許 されており、そのことは発光寿命の温度依存性を調べるこ とで証明できる。量子細線のような 1 次元並進運動を示す 系では、輻射再結合寿命の温度依存性は温度の平方根に比 例する。Fig. 8(b) のように温度を上昇させたときの発光寿
命は $30 \mathrm{~K}$ 以上で見事に温度の平方根に比例する特性を示し た。このことは、励起子ボーア直径以上の高さを有する積 層量子ドットは 1 次元量子細線のように 1 次元方向にエネ ルギーは分散し、ミニバンドを形成していることを示して いる ${ }^{12)}$ 。

ところで、この発光寿命の温度依存性には $30 \mathrm{~K}$ 付近に 変化を示す閾值温度が存在する。 $30 \mathrm{~K}$ 以下の温度では発光 寿命の変化はほぼ同じであり、顕著な変化は観測されない。 このような温度に依存しない発光寿命は孤立した量子ドッ トの特徵である。有限の温度で並進運動が駆動されるとい うことは、温度上昇が量子ドット同士の電子的結合を引き 起こしていることを意味している。低温では不均一に分布 するそれぞれの量子ドットの電子状態のわずかなずれが電 子的結合を阻んでいるが、温度が上昇して量子ドットの励 起子準位のエネルギー均一幅が増加を始めると、上下に隣 り合った量子ドット同士が結合を始め、並進運動をするに いたるのである。

以上のような偏波を制御した量子ドットを利用して、わ れわれは $\mathrm{AlGaAs} / \mathrm{GaAs} / \mathrm{AlGaAs}$ 導波路構造を有する光アン プ構造を作製し、光利得偏波特性を詳しく調べた。光アン プの偏波利得差は実用レベルでは $1 \mathrm{~dB}$ 以内に調整する必 要がある。利得の偏波依存性は注入電流に依存するが、最 適な注入電流の条件下では $50 \mathrm{~nm}$ 以上にわたる偏波無依存 領域を達成することに成功した ${ }^{16)}$ 。また最近、 $1.55 \mu \mathrm{m}$ 帯 で動作する InAs/InP 積層量子ドット光アンプデバイスを試 作し、40 Gbit/s で明暸なアイパターンを観測することに世 界で初めて成功するとともに、光出力 $15.9 \mathrm{dBm}$ を達成し た ${ }^{15)}$ 。

\section{5. 量子ドットの積層方向の制御と光学遷移選択則の変化}

レーザや光アンプのように光導波路構造に量子ドットを 閉じ込めて利用する場合には、上で述べたような制御が不 可欠である。一方、光センサーや太陽電池などのように面 方向からやってくる光を有効に吸収して応答しなければな らない場合には、積層化による洒電子带のミキシングは逆 に不利に働く。このことを理解するために Fig. 9 に先ほど と同様の手法で計算した結果を示す。積層した背の高い量 子ドットの $[001]$ 方向からの傾き角度を $\theta$ として偏光遷移 確率を計算したのが Fig. 9 である。容易にイメージできる ように、積層量子ドットの傾きを増していくと、[001]に平 行な偏光成分は徐々に減少し、(001) 面内の偏光成分の光応 答が増す。このような $(001)$ 面内の光応答の増加は、広い (001) ウエファー面に光が入射する光センサーや太陽電池で は大変有効である。

われわれは最近 In フラックスの照射方向がこの積層方向 を決める重要な因子であることを発見した ${ }^{13)}$ 。量子ドット の MBE 成長時の In フラックスの方向を Fig. 10(a)のよう に斜め 10 度に固定して結晶成長すると、積層した量子ドッ 


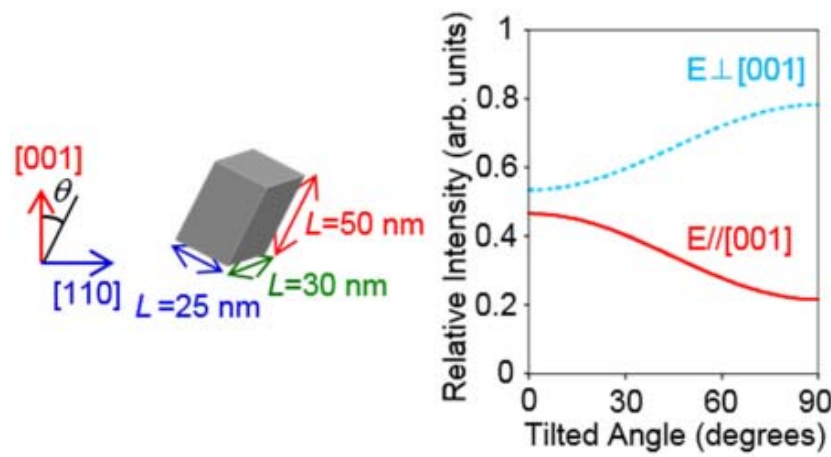

Fig. 9 Calculated transition probabilities of polarization components as a function of (a) QD height and (b) tilted angle against the [001] direction.

(a)

(b)
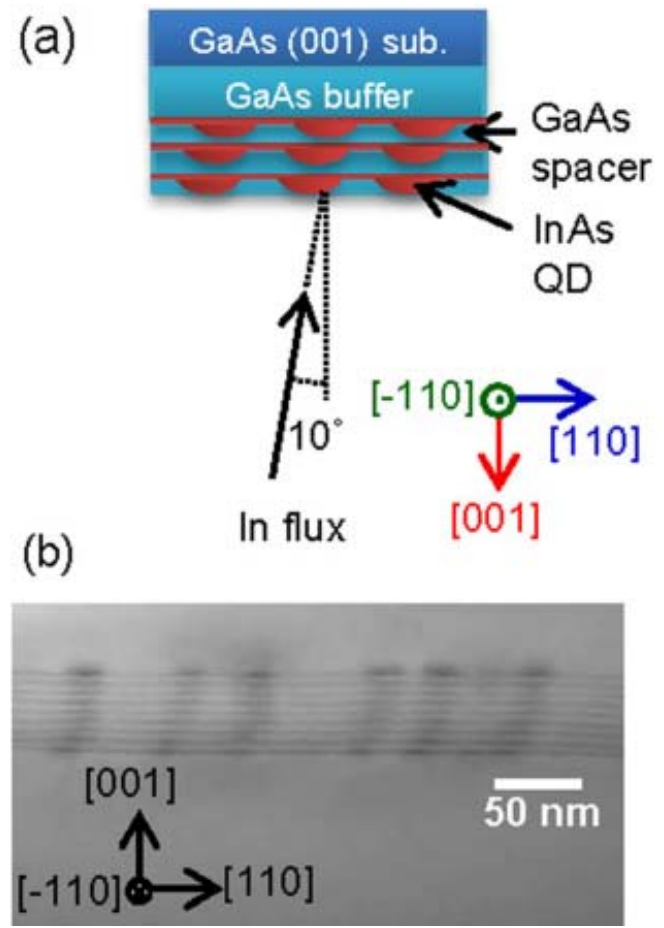

Fig. 10 (-110) and (b) (110)-cross-sectional TEM images of two ninelayer-stacked QDs. Arrows indicate the incident angles of In flux projected against the [001] direction.

トは Fig. 10(b)のようにフラックスの入射方向と同じ 10 度 傾いた方向に積層することを見出した。このときの PL 偏 光光応答特性を Fig. 11 に示す。ここで使用した積層量子 ドットはFig. 10 に示した 9 層積層の量子ドットで、室温 で偏光 PL スペクトルを観測した。(-110) 䢃開面から観測し た直線偏光発光強度は積層量子ドットの傾きに応じて変化 しており、一方、(110) 䢃開面からの発光は積層方向が傾い ていないことを示している。このことは TEM 観察によっ ても確認できており、供給されたInの表面拡散の異方性が (a) From $(-110)$ cleaved edges

(b) From (110) cleaved edges
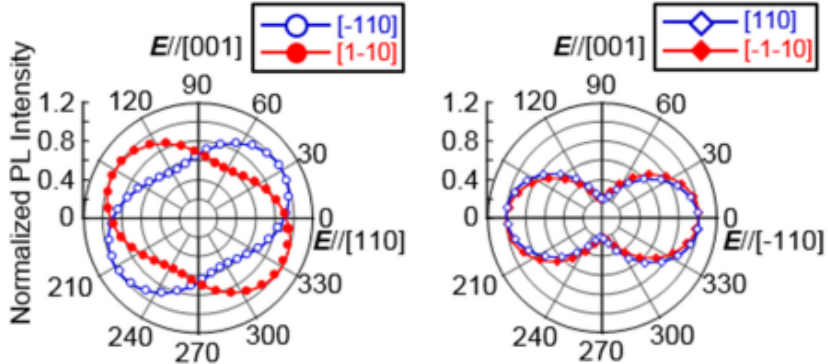

Fig. 11 Polar plots of edge-emitted PL peak intensity from (a) (-110) and (b) (110)-cleaved edges. These are results for the nine-layerstacked QDs without and with substrate rotation, respectively. Blue open circles, red circles, Blue open rhombuses, and Red rhombuses are results from $(-110),(1-10),(110)$, and (-1-10) cleaved edges, respectively.

原因である可能性がある。ところで、Fig. 11 の偏光解析 の結果をよく見ると、傾き角はほぼ 30 度である。これは TEM で観察した結果の 10 度に比べて大きい。この原因は いまだに明らかではないが、2 次元歪分布と合わせて解析 をすることで説明できると考えている。

一方、量子ドットの積層時に基板ホルダーを回転させて 積層量子ドットを成長した場合には、上に述べたような積 層方向の傾きはまったく観測されず、固定した角度での In フラックスの供給が重要であることに間違いないことが明 らかになった。

\section{6. 結 論}

3 次元的に構造が制御された量子ドットはデルタ関数的 な状態密度を有し、これを利用した特徴あるデバイスの設 計が可能である。特に、自己成長機構を利用して作製する InAs/GaAs 自己形成量子ドットは光通信波長帯で動作する 半導体レーザや光中継デバイスには最適であり、偏波制御、 広帯域応答、超高速応答を同時に実現すると期待されてい る。われわれは量子ドットの精密な積層成長技術を開発し、 3 次元的に閉じ込められた量子ドットから 1 次元方向の自 由度を持つ量子細線に連続的に制御して作製した。さらに これまでは不可能であった積層方向を制御する技術の構築 にも成功し、積層量子ドットを利用することで実現できる と期待されている次世代超高性能太陽電池など面型デバイ ス開発の道をひらくことができた。

\section{謝 辞}

本研究を進めるに当たり、量子ドットの電子顕微鏡観察 で大変お世話になった大阪大学の保田英洋先生に深く感 謝します。また、量子ドットの電子状態について普段より 議論している神戸大学の原田幸弘先生、小島磨先生に深く 感謝するとともに、多くの素晴らしい実験データを我慢強 
く測定してくれた学生諸君にこの場をかりて感謝いたしま す。

\section{引用文献}

1) L. Esaki, R. Tsu, IBM J. Res. Devel. 14, 61 (1970).

2) D. Bimberg, M. Grundmann, and N. N. Ledentsov, Quantum Dot Heterostructures (Wiley, New York, 1998) Chap. 8.

3) M. Sugawara, in Semiconductors and Semimetals, ed. M. Sugawara (Academic, San Diego, CA, 1999) Vol. 60, Chap. 6.

4) M. Sugawara, N. Hatori, T. Akiyama, Y. Nakata, and H. Ishikawa, Jpn. J. Appl. Phys. 40, L488 (2001).

5) T. Kita, O. Wada, H. Ebe, Y. Nakata, and M. Sugawara, Jpn. J. Appl. Phys. 41, L1143 (2002).

6) O. Kojima, H. Nakatani, T. Kita, O. Wada, K. Akahane, and M. Tsuchiya, J. Appl. Phys. 103, 113504 (2008).

7) O. Kojima, H. Nakatani, T. Kita, O. Wada, K. Akahane, J. Appl. Phys. 107, 073506 (2010).

8) O. Kojima, N. Tobita, T. Kita, and K. Akahane, J. Appl. Phys. 110, 093515 (2011)

9) T. Kita, N. Tamura, O. Wada, M. Sugawara, Y. Nakata, H. Ebe, and Y. Arakawa, Appl. Phys. Lett. 88, 211106 (2006).

10) Y. Ikeuchi, T. Inoue, M. Asada, Y. Harada, T. Kita, E. Taguchi, and H. Yasuda, Appl. Phys. Express 4, 062001 (2011).

11) M. Usman, T. Inoue, Y. Harada, G. Klimeck, and T. Kita, Phys. Rev.
B 84, 115321 (2011)

12) A. Takahashi, T. Ueda, Y. Bessho, Y. Harada, and T. Kita, E. Taguchi, and H. Yasuda, (Phys. Rev. B 87, 235323 (2013).

13) Y. Bessho, Y. Harada, T. Kita, E. Taguchi, and H. Yasuda, (J. Appl. Phys. 114, 033517 (2013).

14) T. Inoue, M. Asada, N. Yasuoka, O. Kojima, T. Kita, and O. Wada, Appl. Phys. Lett. 96, 211906 (2010).

15) N. Yasuoka, Ph. D Thesis (Kobe University, 2010)

16) M. Suwa, A. Takahashi, T. Ueda, Y. Bessho, Y. Harada, and T. Kita, (submitted to Physica Status Solidi).

17) K. Okajima, K. Takeda, N. Oyama, E. Ohta, K. Shiraishi, and T. Ohno, Jpn. J. Appl. Phys. 39, 917 (2000).

18) T. Kudo, T. Inoue, T. Kita, and O. Wada, J. Appl. Phys. 104, 074305 (2008).

19) T. Kita, T. Inoue, O. Wada, M. Konno, T. Yaguchi, and T. Kamino, Appl. Phys. Lett. 90, 041911 (2007).

20) T. Inoue, T. Kita, O. Wada, M. Konno, T. Yaguchi, and T. Kamino, Appl. Phys. Lett. 92, 031902 (2008).

21) M. Sugawara, N. Hatori, M. Ishida, Hi. Ebe, Y. Arakawa, T. Akiyama, K. Otsubo, T. Yamamoto, and Y. Nakata, J. Phys. D; Appl. Phys. 38, 2126-2134 (2005).

22) M. Sugawara, H. Ebe, N. Hatori, M. Ishida, Y. Arakawa, T. Akiyama, K. Otsubo, and Y. Nakata, Phys. Rev. B 69, 235332 (2004). 